\title{
Digital Advertising and the Marketing Mix: A review of current literature and implications for Higher Education Marketers
}

\author{
Christopher Huebner, MMC, M Ed. University of South Carolina
}

\section{Introduction}

With the allure of targeting and measurability, marketers continue to shift advertising money toward digital channels. In fact, digital advertising has become the fastest growing advertising category, surpassing television spend as of 2017. Breaking down digital advertising into its component categories (display, mobile and social media advertising) all have experienced growth over the past five years. ${ }^{1}$

And while both targeting and measurability are legitimate benefits for advertisers, optimizing for both may not be effective metrics for campaign performance. As ad tech has become more sophisticated, social media sites and programmatic buying platforms alike have given advertisers the ability to "hypertarget" or segment an audience with laser-like precision using very specific buying behaviors, demographic data and audience attributes.

Likewise, the ability to directly measure each effort, in real-time, has turned digital advertising into a direct response vehicle. And like direct response, vendors continue to argue that the best way to optimize campaign performance is to use the click as the important measure for advertising effectiveness. As ad tech has become increasingly more sophisticated, the proselytization of both benefits has continued to emerge.

What has also emerged is a conflicting belief that digital advertising performs similarly to traditional media advertising, or brand advertising. In an effort to hypertarget, marketers are missing out on the need for mass reach, a benefit for long-term brand success.

In fact, Marc Pritchard, chief brand officer of Proctor and Gamble, admitted in The Wall Street Journal that they over played the importance of targeting: "We target too much, and we went too narrow and now we are looking at: what is the right way to get the most reach but also the right precision."

Similarly, when marketers rely on clicks as a measure of advertising effectiveness, they are doing so at the expense of intermediate metrics, which have been shown to be ineffective measures of advertising impact. ${ }^{2}$ As comScore research continues to show, digital advertising

\footnotetext{
${ }^{1}$ The Interactive Advertising Bureau. 2018. "IAB internet advertising revenue report" https://www.iab.com/wpcontent/uploads/2018/11/REPORT-IAB-Internet-Advertising-Revenue-Report-HY-2018.pdf

${ }^{2}$ Fulgoni, Gian M., and Marie Pauline Mörn. 2009. "Whither the Click? How Online Advertising Works." Journal of Advertising Research 49 (2): 134-42.
}

(C) 2019 Christopher Huebner, MMC, M Ed.

This open access article is licensed under a Creative Commons Attribution: Non-Commercial license.

DOI: JMCHE/v1i201 


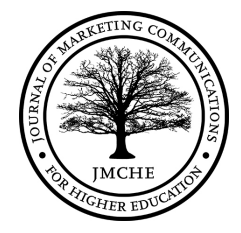

effects should be linked to changes in buying behavior. Their work has shown that digital advertising has the capacity to impact latency effects, branding effects and sales lifts. ${ }^{34}$

Research continues to show that digital advertising does have important brand-level effects. What is more, much of the research indicates that digital advertising - when integrated within a total marketing program - has the potential for greater impact. Thus, examining the effects digital advertising has synergistically with corresponding marketing tactics becomes increasingly important.

This paper seeks to cull relevant research to understand how digital advertising works most effectively with other digital and traditional marketing tactics. Secondly, this paper will take what has been learned outside of the industry and develop direct applications for higher education marketers. Finally, this paper will fill in gaps left by higher education marketers, when it comes to effective use of social media marketing. Much of the higher ed literature examines social media through the lens of organic content and its effects, or "likes" and "favorites," as key performance indicators. Higher ed marketers must begin to look beyond "likes" and "favorites" when measuring marketing effectiveness and examine the potential paid media may have.

For the purpose of this paper, digital advertising will be a catch-all term used for mobile, digital and social media advertising. When necessary, the distinction will be made to highlight the impact of each component.

\section{Measurability}

From last click attribution to geolocation, text-based messaging, ad tech has given advertisers the real-time tools to quantify almost all advertising activities. These tools have dramatically changed how marketers have planned and measured digital advertising campaigns, grounding much of it in direct-response advertising. This digital-as-direct-response evolution has led to the practice of optimizing for clicks, through the manipulation of ad inventory, to increase ROI. ${ }^{5}$ While this may provide a cushion for key performance indicators as well as a spark in short-term marketing performance, the stark reality is click-through rates (CTRs) continue to fall, less than $1 \%$ in most cases. ${ }^{6}$ This optimization often leads to buying cheaper ad inventory, allowing room

\footnotetext{
${ }^{3}$ Fulgoni and Morn. Whither the Click? 134-42.

${ }^{4}$ Fulgoni, Gian M. 2015. "How Brands Using Social Media Ignite Marketing and Drive Growth." Journal of Advertising Research 55 (3): 232-36.

${ }^{5}$ Hollis, Nigel. 2005. "Ten Years of Learning on How Online Advertising Builds Brands." Journal of Advertising Research 45 (2): 255-68.

${ }^{6}$ Fulgoni and Morn. Whither the Click? 134-42.
}

(C) 2019 Christopher Huebner, MMC, M Ed.

This open access article is licensed under a Creative Commons Attribution: Non-Commercial license.

DOI: JMCHE/v1i201 


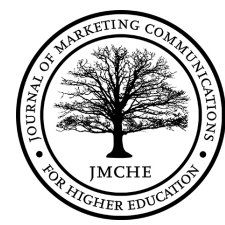

for ad fraud, brand safety and visibility issues. ${ }^{7}$ What is more, many industry studies show that more than half of all clicks are by mistake. ${ }^{89}$

In terms of social media advertising, there has been little evidence to suggest that engagement metrics on social media increase advertising effectiveness. ${ }^{10}$ Similarly, Nielsen continues to examine global social media campaigns and continues to find that CTRs do not correlate with campaign performance (ad recall, brand awareness, purchase intent). ${ }^{11}$

Nielsen also found similar results when examining display advertising CTRs and business impact. Moreover, comScore research has shown no statistical relationship between clicks on display advertisements and the effectiveness of that advertisement. ${ }^{121314}$ Google and Millward Brown have both invested in the health of the digital advertising industry, and continue to promote findings that suggest clicks have little correlation with business objectives. ${ }^{151617}$

\footnotetext{
${ }^{7}$ Bhardwaj, Bhanu and Chris Bacon. 2017. Cookies versus Context: How Contextually Relevant Advertising Drives Consumer Impact; May Improve ROI up to $30 \%$.

https://www.iriworldwide.com/IRI/media/IRI CookiesvsContext TechPaper SinglePage.pdf

${ }^{8}$ Lovelace Jr., Berkeley. 2017. "Half the number of online ad clicks are by mistake, says a Silicon Valley veteran. $C N B C$." https://www.cnbc.com/2017/04/26/half-the-online-ad-clicks-are-by-mistake-says-silicon-valleyveteran.html

${ }^{9}$ Frederick, Ben. 2016. “60\% Of All Mobile Banner Ad Clicks Are Accidents.” MoBlog. https:/www.mediapost.com/publications/article/268266/60-of-all-mobile-banner-ad-clicks-are-accidents.html ${ }^{10}$ Smallwood, Brad. 2016. "Resisting the Siren Call Of Popular Digital Media Measures.” Journal of Advertising Research 56 (2): 126-31

11 The Nielsen Company. 2012. "Click-Thru Rates Mislead Brand Marketers On Online Campaign. ” The Nielsen Company https:/www.nielsen.com/us/en/insights/news/2012/click-thru-rates-mislead-brand-marketers-on-onlinecampaign-performance.html

12 The Nielsen Company. 2016. "Beyond Clicks and Impressions: Examining the Relationship Between Online Advertising and Brand Building." The Nielsen Company https://www.nielsen.com/content/dam/corporate/us/en/reports-downloads/2011-Reports/Nielsen-Beyond-Clicksand-Impressions.pdf

${ }^{13}$ Fulgoni, Gian M. 2013. "Big Data: Friend or Foe of Digital Advertising? Five Ways Marketers Should Use Digital Big Data to Their Advantage." Journal of Advertising Research 53 (4): 372-76.

${ }^{14}$ Wind, Yoram, Byron Sharp and Karen Nelson-Field. 2013. "Empirical Generalizations: New Laws for Digital Marketing: How Advertising Research Must Change.” Journal of Advertising Research 53 (2): 175-80.

${ }^{15}$ Hollis, Nigel. 2012. "Do not optimize on click-through if you want to build your brand online." Millward Brown.com. http://www.millwardbrown.com/global-navigation/blogs/post/mb-blog/2012/07/30/Do-not-optimizeon-click-through-if-you-want-to-build-your-brand-online.aspx

${ }^{16}$ Millward Brown. 2016. "Brand Lift Insights: Maximize advertising impact on brand perceptions." Millward Brown. http://www.millwardbrown.com/mb-global/what-we-do/media-digital/media-effectiveness/brand-liftinsights

${ }^{17}$ Millward Brown. 2017. "Getting Media Right 2017.” Millward Brown

https://www.millwardbrowndigital.com/research-insights/getting-media-right-2017/
}

(C) 2019 Christopher Huebner, MMC, M Ed.

This open access article is licensed under a Creative Commons Attribution: Non-Commercial license.

DOI: JMCHE/v1i201 
As of 2018, investment in mobile advertising has risen to account for 75 percent of all digital ad spend, making it just above $\$ 70$ billion. ${ }^{18}$ According to Fulgoni, while these numbers have increased year-over-year, brands continue to under invest as well as chase the wrong metrics, resulting in marketers underestimating the benefits of mobile advertising. ${ }^{19}$ Like social media and display advertising, most research has found CTRs to be a poor gauge of advertising effectiveness. ${ }^{2021}$ In fact, geolocation firm Retale found that 60 percent of mobile advertising clicks were on accident. ${ }^{22}$

Taken together, a reaction to the growing use of clicks, or intermediate metrics, as effectiveness measures has continued to grow. As noted by Benet and Field in the Long and the Short of It:

"Sadly there appears to be little progress in the world of digital metrics, narrowly concerned as they often are with very short-term responses and questionable metrics such as social media 'likes', often bought with short-term incentives...much work remains to be done to reliably link these to business performance, and the focus of attention appears to lie elsewhere. "23

\section{Targeting}

Digital advertising has opened up a new world for marketers with the ability to track behaviors and target very select audiences using personalized messages. As marketers continued to invest in digital advertising, supply-side providers were quick to evolve media buying practices. For the most part, marketers can buy contextually, meaning the website determines the ad buy-like a television channel - or, behaviorally, meaning the ad buy isn't determined by the website but where the audience moves about from site to site. Currently, the majority of digital advertising is bought programmatically, or using behavioral targeting. ${ }^{24}$

\footnotetext{
${ }^{18}$ Koetsier, John. 2018. "Mobile Advertising Will Drive 75\% Of All Digital Ad Spend In 2018: Here's What's Changing" Forbes https:/www.forbes.com/sites/johnkoetsier/2018/02/23/mobile-advertising-will-drive-75-of-alldigital-ad-spend-in-2018-heres-whats-changing/\#4b84b3d8758b

${ }^{19}$ Fulgoni, Gian M., and Andrew Lipsman. 2017. "Are You Using the Right Mobile Advertising Metrics? How Relevant Mobile Measures Change the Cross-Platform Advertising Equation." Journal of Advertising Research 57 (3): 245-49.

${ }^{20}$ Fulgoni, Gian M., and Marie Pauline Mörn. 2009. "Whither the Click? How Online Advertising Works." Journal of Advertising Research 49 (2): 134-42.

${ }^{21}$ Fulgoni, Gian M., and Andrew Lipsman. 2017. "Are You Using the Right Mobile Advertising Metrics? How Relevant Mobile Measures Change the Cross-Platform Advertising Equation." Journal of Advertising Research 57 (3): 245-49.

${ }^{22}$ Shields, Ronan. 2016. "“Fat thumbs' generate up to $60 \%$ of mobile ad clicks." The Drum. https://www.thedrum.com/news/2016/02/03/fat-thumbs-generate-60-mobile-ad-clicks

${ }^{23}$ Benet, Les. \& Field, Peter. The Long and the Short of It: Balancing Short and Long-Term Marketing Strategies. London: IPA, 2013.

${ }^{24}$ Fisher, Lauren. 2018. “eMarketer Releases Latest US Programmatic Ad Spending Forecast." eMarketer. https://www.emarketer.com/content/emarketer-releases-latest-us-programmatic-ad-spending-forecast
}

(C) 2019 Christopher Huebner, MMC, M Ed.

This open access article is licensed under a Creative Commons Attribution: Non-Commercial license.

DOI: JMCHE/v1i201 


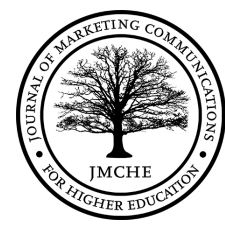

The benefit of hypertargeting is two-fold. First, targeting gives marketers the ability to message to presumably the brand's most high-value customers, improving media efficiency. Secondly, targeting bought programmatically can decrease cost, as cheaper inventory is bought across websites. ${ }^{25}$ In both cases, targeting is meant to reduce advertising waste.

While hypertargeting can be part of a viable short-term strategy, there are technology and advertising effect limitations involved in the practice. For the most part, targeting involves the use of ad cookies. Cookies enable ad servers to identify computers and deliver digital advertising. Unfortunately, cookies are frequently deleted. According to comScore:

"30 percent of U.S. internet users deleted their cookies in a month and do so at an alarming rate of five times per month. "26 As inventory becomes cheaper, viewability becomes an issue. In a subsequent report, comScore calculated nearly half of all display ads are considered 'in-view'.,"27

In terms of advertising effects, over-targeting can lead to ignoring potential customers, loss of cost signaling as a brand equity device and the inability to influence shared/collective meaning. According to Ehrenberg-Bass Institute and marketing professor Byron Sharp, growth is rarely achieved by "relentlessly targeting a particular segment." 28 Over-targeting, with an emphasis on loyal or heavy buyers, has the potential to erode top-of-mind awareness among a majority of category buyers. ${ }^{2930}$ Similar evidence continues to mount from the Ehrenberg-Bass Institute that it is a much better strategy to use advertising to reach as much of the category as possible. ${ }^{31}$ Brands that over target also run the risk of losing cost signaling as a brand equity device. In The Waste in Advertising Is the Part That Works, authors Tim Ambler and E. Ann Hollier found, "perceived expense influences perceptions of brand quality, which in turn is the most critical predictor of a participant's inclination to purchase a brand." 32

\footnotetext{
${ }^{25}$ Bhardwaj, Bhanu and Chris Bacon. 2017. Cookies versus Context: How Contextually Relevant Advertising Drives Consumer Impact; May Improve ROI up to $30 \%$.

https://www.iriworldwide.com/IRI/media/IRI_CookiesvsContext_TechPaper_SinglePage.pdf

${ }^{26}$ Fulgoni, Gian M. 2013. "Big Data: Friend or Foe of Digital Advertising? Five Ways Marketers Should Use Digital Big Data to Their Advantage." Journal of Advertising Research 53 (4): 372-76.

${ }^{27}$ Fulgoni, Gian. M. 2016. "How to maximize the return on investment in digital marketing." WARC. https:/www.warc.com/content/paywall/article/bestprac/how_to_maximize_the_return_on_investment_from_digital marketing/107001

${ }^{\overline{28}}$ Sharp, Byron. How Brands Grow: What Marketers Don't Know. Oxford: Oxford University Press, 2010.

${ }^{29}$ Fulgoni, Gian M. 2018. “Are You Targeting Too Much? Effective Marketing Strategies for Brands.” Journal of Advertising Research 58 (1): 8-11.

${ }^{30}$ Neff, Jeff. "The World According to Byron Sharp." Ad Age. https://adage.com/article/cmo-strategy/the-worldaccording-to-byron-sharp-customer-loyalty-cheating/309532/

${ }^{31}$ Sharp, Byron. How Brands Grow: What Marketers Don't Know. Oxford: Oxford University Press, 2010.

32 Ambler, Tim, and E. Ann Hollier. 2004. "The Waste in Advertising Is the Part That Works." Journal of Advertising Research 44 (4): 375-89.
}

(C) 2019 Christopher Huebner, MMC, M Ed.

This open access article is licensed under a Creative Commons Attribution: Non-Commercial license.

DOI: JMCHE/v1i201 


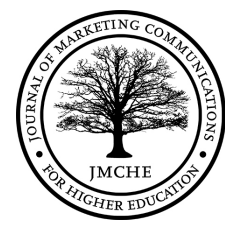

Unfortunately, the ecosystem created to support digital advertising has influenced the quality and predictability of programmatic ad buys which has created an unpredictable and cluttered ad experience. ${ }^{3334}$ Taken together, all three issues affect the perceived quality and intrusiveness of our work. ${ }^{3536}$ And with a near infinite amount of cheap inventory, marketers can set frequency parameters well beyond a traditional measure. Not only do marketers reach diminishing returns rather quickly, the continuous barrage of targeted ads devalues the medium, training users to filter out ads. ${ }^{37}$ Hwang and Kamdar called this filtering the Peak Advertising effect. ${ }^{38}$

Likewise, the more a brand targets, the more the ability to create meaning breaks down. Creating collective meaning is a key way in which advertising works. Not only does mass advertising help create meaning, but also it acts as a signaling device, contextually and in terms of quality. Kevin Simler offers this description:

"[collective meaning] is the mechanism whereby an ad, rather than trying to change our minds individually, changes the landscape of cultural meanings-which in turn changes how we are perceived by others when we use a product." 39

Going to an Ivy League school means something, and the benefits of that education are understood collectively, without the vast majority going to an Ivy League school.

Summed up by Les Binet and Peter Field:

"...the way in which long-term effects are generated is fundamentally different from how most short-term effects are produced. Although long-term effects always produce some short-term effects, the reverse is not true and long-term effects are not simply an accumulation of short-term effects. " 40

\footnotetext{
${ }^{33}$ Bernard, M. 2001. Developing Schemas for the Location of Common Web Objects. Human Factors and Ergonomics Society Annual Meeting Proceedings. 45(15):1161-1165.

${ }^{34}$ Ha, Louisa, and Kim McCann. 2008. "An Integrated Model of Advertising Clutter in Offline and Online Media." International Journal of Advertising 27 (4): 569-92.

${ }^{35}$ Kuisma, Jarmo. "Consumer Perception of Online Advertising: The Effects of Animation, Ad Characteristics, Repetition, Task Relevancy on Attention and Memory." (Unpublished doctoral dissertation, Aalto University, Helsinki, Finland, 2015).

${ }^{36}$ Hoglund, G. \& Syvertsson, A. (2018). The causes and effects of native advertising clutter in social media. (Master's thesis, Stockholm School of Economics. Retrieved from http://arc.hhs.se/download.aspx?MediumId=4050

${ }^{37}$ Hervet, Guillaume, Katherine Guérard, Sébastien Tremblay, and Mohamed Saber Chtourou. 2011. "Is Banner Blindness Genuine? Eye Tracking Internet Text Advertising." Applied Cognitive Psychology 25 (5): $708-16$.

${ }^{38}$ Hwang, Tim and Adi Kamdar. 2013. "The Theory of Peak Advertising And the Future of the Web." Nesson Center for Internet Geophysics http://peakads.org/images/Peak_Ads.pdf

${ }^{39}$ Simler, Kevin. 2014. “Ads Don't Work That Way.” Melting Asphalt. https://meltingasphalt.com/ads-dont-workthat-way/

${ }^{40}$ Benet, Les. \& Field, Peter. The Long and the Short of It: Balancing Short and Long-Term Marketing Strategies. London: IPA, 2013.
}

(C) 2019 Christopher Huebner, MMC, M Ed.

This open access article is licensed under a Creative Commons Attribution: Non-Commercial license.

DOI: JMCHE/v1i201 


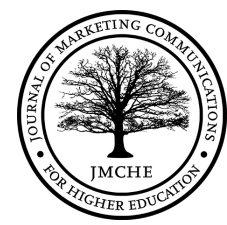

In review, the web and social media platforms have given marketers unprecedented access to data and people. For the most part, this has led to an overwhelming use of direct response methods and metrics. ${ }^{4142}$ To no one's fault this was how the digital advertising ecosystem was built. In a 2000 examination of online news journals, Hollis, found that there was a 2:1 ratio in favor of the view that online advertising could not build brands. ${ }^{43}$

Practitioners have begun to question the buying and selling practices of programmatic, viewability issues and brand safety concerns. This has placed a new interest in digital advertising's ability to brand build as well as impact advertising effects across media.

\section{Brand Building, Digitally}

In many ways, the web and social media performs like traditional media. Both provide a platform to reach large audiences through paid media. Unfortunately, engagement and intermediate metrics have chipped away at the importance of reach. Furthermore, as consumers continue to adopt to rapid media environments, behavior is becoming increasingly passive as well as the development of "banner blindness." 44

\section{As Jerry Daykin writes:}

“...digital [advertising] is most effective when it plays by traditional rules, but does so better than traditional media can. The real advantage of digital is often when it can help us broadly reach more consumers, not specifically target fewer. " 45

As noted above, evidence continues to mount from the Ehrenberg-Bass Institute that it is a much better strategy to use advertising to reach as much of the category as possible. ${ }^{46}$ In tandem, digital advertising can greatly extend the reach of more traditional advertising tactics as well as other digital marketing tactics. ${ }^{47}$ More specifically, research on social media advertising found that one of the top factors influencing social media advertising was content reach. ${ }^{48}$ In fact,

\footnotetext{
${ }^{41}$ Hollis, Nigel. 2005. “Ten Years of Learning on How Online Advertising Builds Brands.” Journal of Advertising Research 45 (2): 255-68.

42 Biglione, Shann. To Target Or Not To Target, That Is Not The Question. In Snijders, W (Eds.), Eat Your Greens: Fact-based thinking to improve your brand's health. Leicester: Matador Publishing, 2018.

${ }^{43}$ Hollis, Nigel. Ten Years of Learning on How Online Advertising Builds Brands. 255-68.

${ }^{44}$ Hwang, Tim and Adi Kamdar. 2013. "The Theory of Peak Advertising And the Future of the Web." Nesson Center for Internet Geophysics http://peakads.org/images/Peak_Ads.pdf

45 Daykin, Jerry. 2016. "The Wizarding World of Digital Marketing." LinkedIn.

https:/www.linkedin.com/pulse/wizarding-world-digital-marketing-digitalsense-jerry-daykin/?forceNoSplash=true

${ }^{46}$ Romaniuk, Jenni and Byron Sharp. How Brands Grow: Part 2: Emerging Markets, Services, Durables, New and Luxury Brands. Oxford: Oxford University Press, 2015.

${ }^{47}$ Fulgoni, Gian M. 2018. "Are You Targeting Too Much? Effective Marketing Strategies for Brands.” Journal of Advertising Research 58 (1): 8-11.

${ }^{48}$ Raudeliuniene, Jurgita, Vida Davidaviciene, Manuela Tvaronaviciene and Laimonas Jonuska. 2018. "Evaluation of Advertising Campaigns on Social Media Networks." MDPI
}

(C) 2019 Christopher Huebner, MMC, M Ed.

This open access article is licensed under a Creative Commons Attribution: Non-Commercial license.

DOI: JMCHE/v1i201 


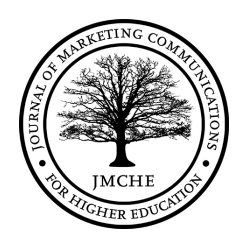

Facebook Business instructs brands on the importance of reach, as part of their suite of educational platforms for businesses. ${ }^{49}$

In Media in Focus: Marketing Effectiveness in the Digital Age, Binet and Field discussed communications meant to brand build, do so in five distinct ways: Creates strong mental structures through repeat exposures, influences future sales, has broad reach, has long-term implication and relies on emotional priming. ${ }^{50}$ Leaving behind the belief that digital is solely meant for highly-targeted advertising and driven by direct-response type marketing objectives, digital advertising has been proven to provide many benefits to long-term brand building as well as improve multi-platform campaign effectiveness.

The next section will cover how digital advertising affects consumer behavior and brand-related metrics. After the literature is reviewed, a series of implications for higher ed marketers will be listed.

\section{Digital Advertising Effects}

The tendency to equate the lack of impressive digital metrics - CTRs and impression — with ability to impact consumer behavior and brand-related metrics is misguided. Aside from exposure, digital advertising has shown the ability to affect meaningful measures, such as sales, cost per impact and brand awareness. ${ }^{5152}$

As early as 1997, the Interactive Advertising Bureau (IAB) has sought to fund studies examining digital advertising's brand building efficacy. During this period the IAB showed noticeable effects on consumer attitude and behavior. ${ }^{53}$ Around this same time, Millward Brown was testing the effects of digital advertising using its AdIndex and MarketNorms databases. ${ }^{54}$ This early Millward Brown research found display advertising increased unaided and total brand awareness. $^{55}$

\footnotetext{
${ }^{49}$ Facebook IQ. 2016. "Reach Matters: Driving Business Results at Scale.” Facebook Business. https://scontentiad3-1.xx.fbcdn.net/v/t39.23656/18159135_1778340622479708_1200639772381413376_n.pdf?_nc_cat=104\&_nc_ht=scontent-iad31.xx\&oh=3c3f7a3de4e581da5e2fb75e2ba461 $\mathrm{cf} \&$ oe $=5 \mathrm{CF} 148 \mathrm{~B} 1$

${ }^{50}$ Benet, Les \& Field, Peter. Media in Focus: Marketing Effectiveness in the Digital Age. London: IPA, 2017. https:/effworks.co.uk/wp-content/uploads/2017/10/MEDIA_IN_FOCUS_FINAL_PDF_909.pdf

${ }^{51}$ Knoll, Johannes. 2016. “Advertising in Social Media: A Review of Empirical Evidence." International Journal of Advertising 35 (2): 266-300.

${ }^{52}$ Benet, Les \& Field, Peter. Media in Focus: Marketing Effectiveness in the Digital Age. London: IPA, 2017. https:/effworks.co.uk/wp-content/uploads/2017/10/MEDIA_IN_FOCUS_FINAL_PDF_909.pdf

${ }^{53}$ Millward Brown Interactive. "1997 IAB Online Advertising Effectiveness Study”. San Francisco, CA: Millward Brown Interactive, 1997.

${ }^{54}$ Millward Brown and Hotwired. 1996. The Hotwired Advertising Effectiveness Study. Hotwired.

${ }^{55}$ Hollis, Nigel. 2001. "Is Bigger Really Better?” ESOMAR Latin American Conference.
}

(C) 2019 Christopher Huebner, MMC, M Ed.

This open access article is licensed under a Creative Commons Attribution: Non-Commercial license.

DOI: JMCHE/v1i201 


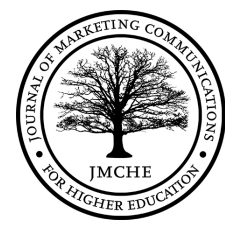

More recent studies have indicated display advertising's ability to increase sales, brand consideration and likelihood to buy. ${ }^{5657}$ Researchers examining the use of high-impact digital advertising formats, in relation to overall digital marketing mix, found that high-impact ads showed substantial lifts in brand recall and brand recognition, in comparison to standard display units. Aside from exposure, they found that high-impact digital advertising could improve subsequent ad exposures, even at the cost of moving from high-impact units to standard display units. $^{58}$

The link between digital advertising and sales has been established across display and mobile. ${ }^{59}$ Across 20 different digital campaigns, Bhardway and Bacon found that digital advertising, when aligned with the brand campaign, were shown to increase ROI by up to 30 percent. Researchers continued to see improvements in sales lifts when ad buy was done contextually, instead of programmatically. ${ }^{60}$

comscore examined 139 display advertising campaigns across a variety of industries and found that display advertising increased web traffic, on average of 46 percent, over a four-week period. $^{61}$

\section{Implications}

- New work examining the "the rule three," in terms of advertising exposure, have found that effects are stronger beyond an average frequency of $10 .{ }^{62}$ This is especially prevalent in display advertising. Studies have extended this notion, as it relates to high-involvement categories. In a sense, more exposures are needed to achieve optimal brand effects. ${ }^{63}$ Foregoing the three-to-10 benchmark is important in our current media environment and

\footnotetext{
${ }^{56}$ Hollis, Nigel. 2005. “Ten Years of Learning on How Online Advertising Builds Brands.” Journal of Advertising Research 45 (2): 255-68.

${ }^{57}$ Manchanda, Puneet, Jean-Pierre Dubé, Khim Yong Goh, and Pradeep K. Chintagunta. 2006. "The Effect of Banner Advertising on Internet Purchasing." Journal of Marketing Research (JMR) 43 (1): 98-108.

${ }^{58}$ Baron, Shawn D., Caryn Brouwer, and Amaya Garbayo. 2014. "A Model for Delivering Branding Value Through High-Impact Digital Advertising." Journal of Advertising Research 54 (3): 286-91

${ }^{59}$ Lewis, Randall A., and Justin M. Rao. 2015. "The Unfavorable Economics of Measuring the Returns to Advertising." Quarterly Journal of Economics 130 (4): 1941-73.

${ }^{60}$ Bhardwaj, Bhanu and Chris Bacon. 2017. Cookies versus Context: How Contextually Relevant Advertising Drives Consumer Impact; May Improve ROI up to $30 \%$.

https://www.iriworldwide.com/IRI/media/IRI_CookiesvsContext_TechPaper_SinglePage.pdf

${ }^{61}$ Fulgoni, Gian M., and Marie Pauline Mörn. 2009. "Whither the Click? How Online Advertising Works." Journal of Advertising Research 49 (2): 134-42.

${ }^{62}$ Burton, Jennifer Lee, Jan Gollins, Linda E. McNeely, and Danielle M. Walls. 2019. "Revisiting the Relationship between Ad Frequency and Purchase Intentions: How Affect and Cognition Mediate Outcomes At Different Levels of Advertising Frequency." Journal of Advertising Research 59 (1): 27-39.

${ }^{63}$ Cauberghe, Verolien, and Patrick De Pelsmacker. 2008. "The Advertising Impact of an Interactive TV Program on the Recall of an Embedded Commercial." Journal of Advertising Research 48 (3): 352-62.
}

(C) 2019 Christopher Huebner, MMC, M Ed.

This open access article is licensed under a Creative Commons Attribution: Non-Commercial license.

DOI: JMCHE/v1i201 
helps with uneven frequency distribution. ${ }^{64}$ Given the longer customer journey and highinvolvement category, higher ed marketers should favor a much more liberal approach to frequency capping. While research examining ad frequency beyond 10 is limited, the research above indicates that consumers have "a much higher threshold for advertising repetition." 65 Considering this, messaging can evolve as the prospective student enters the recruitment funnel and moves from prospect to inquiry, and then on to applicant. As Belch and Belch found, consumers exposed to an advertisement from three to 10 times are influenced by ads that help them with information seeking. ${ }^{66}$

- Given the brand-lifting effects display advertising has shown, higher ed marketers, when budgets are limited, should treat display advertising much like television advertising and target important geographical markets. Advertising Research Foundation research indicates online digital advertising had similar branding effects than an identical television advertisement. ${ }^{67}$

\section{Social Media Advertising Effects}

While new ad types and platforms continue to increase and evolve, the bulk of current research focuses on Facebook. In many cases, the focus is on social media as word-of-mouth or as organic posts. ${ }^{68}$ With the emergence of Spotify and the growth of video, in terms of pre-roll on streaming services and YouTube, there is still much to learn in this space. ${ }^{69}$

Dao et al. found that a social media advertisement's informativeness, entertainment and credibility influenced its perceived value, which in turn influenced purchase intent. Effects were more pronounced with YouTube users. ${ }^{70}$ The built-in social proof mechanism of some social media ad units was seen to positively impact ad affinity. ${ }^{71}$ According to Google, brand performance (awareness, recall, consideration) increased when users were exposed to more than

\footnotetext{
${ }^{64}$ Shebbeare, Andrew. 2014. "Everything You Know About Frequency is Wrong." AdExchanger. http://adexchanger.com/data-driven-thinking/everything-know-frequency-wrong/

${ }^{65}$ Burton, Jennifer Lee, Jan Gollins, Linda E. McNeely, and Danielle M. Walls. 2019. "Revisiting the Relationship between Ad Frequency and Purchase Intentions: How Affect and Cognition Mediate Outcomes At Different Levels of Advertising Frequency." Journal of Advertising Research 59 (1): 27-39.

${ }^{66}$ Belch, George E. \& Belch, Michael A. Advertising and Promotion: An Integrated Marketing Communications Perspective. New York: McGraw-Hill Education, 2015.

${ }^{67}$ Advertising Research Foundation. 2018. Video impact: The value of mass marketing compared to targeting. WARC. https://www.warc.com/content/article/arf-

kif/video_impact the_value_of_mass_marketing_compared_to_targeting/122944

${ }^{68}$ Knoll, Johannes. 2016. "Advertising in Social Media: A Review of Empirical Evidence.” International Journal of Advertising 35 (2): 266-300.

${ }^{69}$ Blumenstein, Howard and Brianne Janacek Reeber. 2017. "5 charts that prove viewability and audibility together are key to video ad effectiveness." Think with Google. https:/www.thinkwithgoogle.com/advertisingchannels/video/effective-video-ads-viewability-audibility/

${ }^{70}$ Dao, William Van-Tien, Angelina Nhat Hanh Le, Julian Ming-Sung Cheng and Der Chao Chen. 2014. "Social media advertising value." International Journal of Advertising, 33 (2), 271-294.

${ }^{71}$ Tan, Wei Son, Choon Ling Kwek and Zhongwei Li. 2013. "The Antecedents of Effectiveness Interactive Advertising in the Social Media.” International Business Research. 6(3). 88-89.
}

(C) 2019 Christopher Huebner, MMC, M Ed.

This open access article is licensed under a Creative Commons Attribution: Non-Commercial license.

DOI: JMCHE/v1i201 


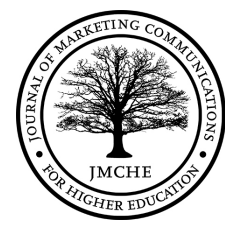

three seconds of a YouTube ad. In terms of driver of purchase decisions, Powers, Advincula, Austin, Graiko, et al. found that emotion was the most important influence in the effectiveness of social media advertising. ${ }^{72}$

Within luxury goods, research indicates social media advertising has increased purchase intention, as well. ${ }^{737475}$ While not marketing-based research, Alhabash, McAlister, et al. found that ad exposure on Facebook increased purchase consideration of alcoholic beverages. ${ }^{76}$ Lysol combined a sophisticated look at their consumer's path to purchase with appropriate seasonal messages (purchase stages: know, feel, compare, purchase, use, bond, recommend) to drive brand preference measures and sales. An analysis of the campaign showed that social media advertising had the greatest impact when focusing on the compare stage. ${ }^{77}$

\section{Implications}

- Twitter and Facebook advertising provides more flexibility for messaging that drives comparison. The key is to develop a thorough understanding of how students move through the college search process to assess where comparison messaging may provide the most impact. This may grow in importance as behavior on social media sites becomes increasingly passive and purchase-related behavior is less likely.

\section{Mobile Advertising Effects}

Historically, much of the literature examines mobile advertising's effect on conversions as well as categorizes SMS text messages as a mobile advertising-based tactic. In terms of specific mobile advertising units, mobile advertising has increased brand attitudes and purchase

\footnotetext{
72 Powers, Todd, Dorothy Avdinccula, Manila S. Austin, Stacy Graiko, and Jasper Snyder. 2012. "Digital and Social Media In the Purchase Decision Process: A Special Report from the Advertising Research Foundation." Journal of Advertising Research 52 (4): 479-89.

${ }^{73}$ Shu-Chuan Chu, Sara Kamal \& Yoojung Kim. 2013. "Understanding consumers' responses toward social media advertising and purchase intention toward luxury products.” Journal of Global Fashion Marketing. 4 (3), $158-174$.

${ }^{74}$ Donvito, Raffaele., \& Raithel, Sascha. 2014. "Marketing mix and customer equity of SPA brands: Cross-cultural perspectives.” Journal of Business Research. 67 (10), 2155-2163.

75 Shu-Chuan Chu, Sara Kamal \& Yoojung Kim. 2019. "Re-examining of consumers' responses toward social media advertising and purchase intention toward luxury products from 2013 to 2018: A retrospective commentary." Journal of Global Fashion Marketing. 10 (1), 81-92.

${ }^{76}$ Alhabash, Saleema, Anna R. McAlister, Wonkyung Kim, Chen Lou, Carie Cunningham, Elizabeth Taylor Quilliam \& Jef I. Richards. 2016. "Saw It on Facebook, Drank It at the Bar! Effects of Exposure to Facebook Alcohol Ads on Alcohol-Related Behaviors.” Journal of Interactive Advertising. 16 (1): 44-58.

${ }^{77}$ Chappell, Matt. (ND). "Measuring the effectiveness of social media for FMCG." IPA Social Works. https://www.marketingsociety.com/sites/default/files/LYSOLCASESTUDY_2\%281\%29.PDF
} 


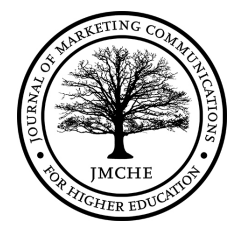

intent. $^{787980}$ This effect was more pronounced in high-involvement categories versus lowinvolvement categories. ${ }^{81}$ Ghose, Han and Park found that mobile advertising, when paired with display, triggered more clicks. ${ }^{82}$ Fulgoni and Lipsman found that mobile advertising performed better, in terms of reaching target audiences and were less affected by invalid traffic. Between 2014-2016 comScore found mobile consistently added to brand-level effects throughout the marketing funnel (awareness to purchase intent). ${ }^{83}$

As part of the Mobile Marketing Association's industry-wide, Smart Cross-Marketing Effectiveness Research initiative, researchers conducted a series of brand-funded case studies across four countries. Among the studies, research funded by Walmart found that mobile advertising was twice as effective at driving sales (and purchase intent) as the average tactics of their campaign, primarily using geolocation targeting. Studies funded by The Coca-Cola Company and Unilever Magnum Ice Cream had similar results using mobile video advertising units. $^{84}$

An AllState case study showed how mobile could be used to brand build as well as direct response. In terms of the study, the two main communication objectives were: reinforce brand image and increase consideration among broader groups who might not be in-market and use media to trigger immediate response for those in-market. Using mobile display, mobile audio and mobile video, Allstate found that top-of-the-funnel metrics (perceptions and consideration) were most affected by mobile audio and video. At the bottom of the funnel, mobile display proved to be efficient in driving sales. ${ }^{85}$

\footnotetext{
${ }^{78}$ Pappachen, George and Kara Manatt. 2008. "The Mobile Brand Experience: Measuring Advertising Effectiveness on the Mobile Web." ESOMAR. www.esomar.org/web/research papers/Advertising-Research_1828_The-MobileBrand-Experience.php]

${ }^{79}$ Nielsen. (2012). State of the Media: U.S. Digital Consumer Report. https://www.slideshare.net/blueeyepathrec/

${ }^{80}$ Bart, Yakov, Andrew T. Stephen, and Miklos Sarvary. 2014. "Which Products Are Best Suited to Mobile Advertising? A Field Study of Mobile Display Advertising Effects on Consumer Attitudes and Intentions." Journal of Marketing Research (JMR) 51 (3): 270-85.

${ }^{81}$ Bart, Yakov, Andrew T. Stephen, and Miklos Sarvary. 2014. "Which Products Are Best Suited to Mobile Advertising? A Field Study of Mobile Display Advertising Effects on Consumer Attitudes and Intentions." Journal of Marketing Research (JMR) 51 (3): 270-85.

${ }^{82}$ Ghose, Anindya, Avi Goldfarb, and Sang Pil Han. 2013. "How Is the Mobile Internet Different? Search Costs and Local Activities." Information Systems Research 24 (3): 613-31.

${ }^{83}$ Fulgoni, Gian M., and Andrew Lipsman. 2017. "Are You Using the Right Mobile Advertising Metrics? How Relevant Mobile Measures Change the Cross-Platform Advertising Equation." Journal of Advertising Research 57 (3): 245-49.

${ }^{84}$ Bakopoulos, Vassilis, John Baronello, and Rex Briggs. 2017. "How Brands Can Make Smarter Decisions in Mobile Marketing: Strategies for Improved Media-Mix Effectiveness And Questions for Future Research." Journal of Advertising Research 57 (4): 447-61.

${ }^{85}$ Bakopoulos, Vassilis, John Baronello, and Rex Briggs. 2017. "How Brands Can Make Smarter Decisions in Mobile Marketing: Strategies for Improved Media-Mix Effectiveness And Questions for Future Research." Journal of Advertising Research 57 (4): 447-61.
} 


\section{Implications}

- Mobile creates more granular targeting opportunities. Combined with geofencing, taking a direct response approach may work better when driving event or campus visit registrations within a close proximity.

- In terms of upper funnel metrics, especially brand awareness, mobile display advertising is most effective. When budget is limited, mobile may offer best cross-channel synergy. Given the environment, use clear, single-minded messaging. ${ }^{86}$

\section{Digital Advertising in the Marketing Mix}

The biggest potential, in terms of digital advertising, rests in how it relates to other parts of the marketing mix. ${ }^{87}$ When used as part of a multichannel campaign, exposure across multiple platforms may lead to stronger pattern recognition, less wear-out and increased credibility of brand. ${ }^{888990}$ Similarly, first exposure may prime and with subsequent exposures via other channels, drive message comprehension for creative strategies that align across campaigns as well as consumer behavior. ${ }^{9192}$

By examining the complex nature of the digital advertising ecosystem, paired with the possibility of strengthening marketing and recruitment goals, this section will highlight the synergistic effects when digital advertising and other channels are integrated.

\section{Digital and Search}

There is synergy between digital and search advertising. Not only does digital advertising drive search within a category (and generic category search terms), but has been shown to generate a greater average lift in brand-related searches. ${ }^{93}$

\footnotetext{
${ }^{86}$ Stuart, Greg, Vassilis Bakopoulos and Rex Briggs. 2016. "Why mobile marketing is a missed opportunity- And how you can optimize it on behalf of your brand." Journal of Brand Strategy. 5(2). 1-10.

${ }^{87}$ Benet, Les \& Field, Peter. Media in Focus: Marketing Effectiveness in the Digital Age. London: IPA, 2017. https://effworks.co.uk/wp-content/uploads/2017/10/MEDIA_IN_FOCUS_FINAL_PDF_909.pdf

${ }^{88}$ Naik, Prasada A., and Kalyan Raman. 2003. "Understanding the Impact of Synergy in Multimedia Communications.” Journal of Marketing Research (JMR) 40 (4): 375-88.

${ }^{89}$ Navarro-Bailón, MaríaÁngeles. 2012. "Strategic Consistent Messages in Cross-Tool Campaigns: Effects on Brand Image and Brand Attitude." Journal of Marketing Communications 18 (3): 189-202.

${ }^{90}$ Neijens, Peter, and Hilde Voorveld. 2015. "Cross-Platform Advertising: Current Practices and Issues for the Future." Journal of Advertising Research 55 (4): 362-67.

${ }^{91}$ Laroche, Michel, Isar Kiani, Nectarios Economakis, and Marie-Odile Richard. 2013. "Effects of Multi-Channel Marketing on Consumers' Online Search Behavior: The Power of Multiple Points of Connection." Journal of Advertising Research 53 (4): 431-43.

9292 Snyder, Jasper, and Manuel Garcia-Garcia. 2016. “Advertising across Platforms: Conditions for Multimedia Campaigns.” Journal of Advertising Research 56 (4): 352-67.

${ }^{93}$ Fulgoni, Gian M., and Marie Pauline Mörn. 2009. "Whither the Click? How Online Advertising Works." Journal of Advertising Research 49 (2): 134-42.
} 
A 2006 Google and comScore study found that digital advertising generated a greater average lift in search results using generic terms, meaning category search queries versus brand search. ${ }^{94}$ Fulgoni and Lipsman found that, in comparison to the control group, individuals exposed to search-only advertising, display-only advertising and search and display combined showed statistically significant sales lift. ${ }^{95}$ When applying a multi-channel marketing mix, search behavior increased the more channels an audience was exposed. ${ }^{96}$

In the 2014 study reported above, of the three non-control groups, those exposed to digital advertising and search advertising showed a much higher sales lift. According to Fulgoni and Lipsman, "What was notable, however, was that the lift was significantly higher than would have been expected based on the lifts achieved by the search-only and display-only groups."

\section{Implications}

- Brand-related search queries occur more frequently in the short-term. ${ }^{97}$ In relation to digital advertising schedules, higher ed marketers should create media plans that optimize keywords for brand-related queries first and optimize category keywords during the longtail.

- In terms of message synergy, digital advertising can use emotion to drive action and use search to provide a compelling "reason to believe," as prospective student moves from awareness to intent.

\section{Digital Advertising and Television}

While targeting was perceived to be the holy grail for advertisers, digital advertising quietly became an effective way to extend the reach of higher cost media. As early as 2004, researched began to explore the synergy created by the combination of television and digital advertising. Until recently, the work focused on attitude toward ad and brand. Chang and Thorson found that the effects produced between television and digital advertising were more distinctive due to the different ways both ad units were processed. It wasn't necessarily about repetition but messages from multiple sources that lead to higher processing levels in participants. ${ }^{98}$

\footnotetext{
${ }^{94}$ Google \& comScore. 2006. "comScore Press Release Study Confirms the Importance of Search in influencing Offline buying." comScore. http://www.comscore.com/press/release.asp?press=796

${ }^{95}$ Fulgoni, Gian M., and Andrew Lipsman. 2014. "Digital Game Changers: How Social Media Will Help Usher in The Era of Mobile and Multi-Platform Campaign-Effectiveness Measurement." Journal of Advertising Research 54 (1): 11-16.

${ }^{96}$ Laroche, Michel, Isar Kiani, Nectarios Economakis, and Marie-Odile Richard. 2013. "Effects of Multi-Channel Marketing on Consumers' Online Search Behavior: The Power of Multiple Points of Connection." Journal of Advertising Research 53 (4): 431-43.

${ }^{97}$ Laroche, Michel, Isar Kiani, Nectarios Economakis, and Marie-Odile Richard. 2013. "Effects of Multi-Channel Marketing on Consumers' Online Search Behavior: The Power of Multiple Points of Connection." Journal of Advertising Research 53 (4): 431-43.

${ }^{98}$ Chang, Yuhmiin and Thorson, Esther. 2004. "Television and Web Advertising Synergies." Journal of Advertising 33 (2): 75-84.
}

(C) 2019 Christopher Huebner, MMC, M Ed.

This open access article is licensed under a Creative Commons Attribution: Non-Commercial license.

DOI: JMCHE/v1i201 


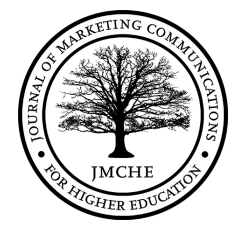

More current research focuses on what Snyder and Garcia-Garcia call the "kicker effect," which suggests that digital connects with the consumer in a very specific way to add value to the television campaign. The added value being more about brand metrics than affinity toward ad. There were also behavioral implications. The "kicker effect" describes the propensity for television advertising to drive search behavior. As consumers turn toward the web to research or simply browse with intent, they will more than likely be exposed to and notice the ad. ${ }^{99}$

Snyder and Garcia-Garcia found that when mobile advertising was combined with television, participants demonstrated 62 percent free recall and 39 percent weighted purchase intent. What was interesting about the findings was the order in which consumers were exposed. Scores were significantly higher when mobile advertising followed the television advertising. Similarly, when the effects were examined by category, "higher-involvement" categories scored higher in impact. ${ }^{100}$

\section{Implications}

- Do major collegiate athletic events trigger the same perceptual drivers that ads do? If so, use digital advertising to efficiently extend the reach of the event. Similarly, are there parallels between athletic event and brand messaging? If so, digital advertising has the ability to drive brand metrics along with the athletic event-driven awareness.

- In terms of message synergy, use television to drive emotion and use digital advertising to drive message comprehension. And when aligned, find which aspects are more likely to trigger perceptions of relevance and use them to drive information seeking. ${ }^{101}$ Consider the television and digital advertising mix Apple uses to promote new products. The brand uses social media advertising as a supplement to its television campaigns. Television is used to drive large-scale reach, while social media extends reach and reinforces brand messaging.

While there is still much to uncover, in terms of evaluating the integration of digital advertising with other components of the marketing mix, there is enough research to encourage new ways of structuring marketing and recruitment campaigns. Along with print and email, customer journeys that span multiple years, gives higher ed marketers a large, and in some cases a daunting, canvas to plan campaigns.

\section{Consider the Entire Journey}

Perhaps the most interesting guidepost comes from the advertising frequency literature. More specifically, research that examines frequency across the entire customer journey. Burton,

\footnotetext{
${ }^{99}$ Snyder, Jasper, and Manuel Garcia-Garcia. 2016. "Advertising across Platforms: Conditions for Multimedia Campaigns." Journal of Advertising Research 56 (4): 352-67.

${ }^{100}$ Snyder, Jasper, and Manuel Garcia-Garcia. 2016. "Advertising across Platforms: Conditions for Multimedia Campaigns.” Journal of Advertising Research 56 (4): 352-67.

${ }^{101}$ Hollis, Nigel. 2005. "Ten Years of Learning on How Online Advertising Builds Brands." Journal of Advertising Research 45 (2): 255-68.
}

(C) 2019 Christopher Huebner, MMC, M Ed.

This open access article is licensed under a Creative Commons Attribution: Non-Commercial license.

DOI: JMCHE/v1i201 


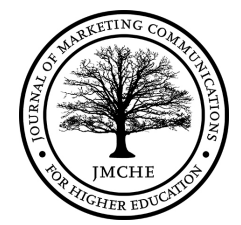

Gollins, McNeely and Walls show that to maximize purchase intention, marketers should strive for an average frequency beyond 10 exposures. Their research findings were used to develop a theoretical framework for marketers to develop advertising messaging architecture. In terms of strategy, they provide clarity when linking the "number of exposures to an advertisement to consumers' underlying purchase motivations, on the basis of their stage in the hierarchy of advertising effects or the consumer decision-making process." 102

Their model proposes the importance of emotion when guiding purchase decisions early in the "persuasion process," usually around the one to two exposure mark. At this stage (Labeled: "Pay Attention"), it is the marketer's job to use emotion to motivate the consumer to pay attention. In terms of the consumer, the decision-making process starts with problem recognition. At this stage, the focus should be on gaining attention through emotional drivers using category benefits (i.e. college search).

As information-processing and decision-making processes take shape, at the post-problem recognition phase, cognitive forces take over (message comprehension, message acceptance, message retention). According to Burton et al., consumers attach meaning to the symbols the advertising conveys and decide if the message is consistent with their current belief system. Understanding this phase (Labeled: "Purchase Consideration and Evaluation") should help with message creation as consumers move from third to tenth exposure to advertisement. Messages should align with information seeking behavior. As consumers are learning more about colleges and schools, they are comparing benefits. Under this model, messaging should align with distinct product benefits and reasons to believe the value proposition. ${ }^{103}$

The final stage is the purchase decision (Labeled "Action"), which suggests that purchase decisions are more strongly influenced by emotion. In a sense, the emotion is used to reinforce the rational decision-making process. ${ }^{104}$

\footnotetext{
${ }^{102}$ Burton, Jennifer Lee, Jan Gollins, Linda E. McNeely, and Danielle M. Walls. 2019. "Revisiting the Relationship between Ad Frequency and Purchase Intentions: How Affect and Cognition Mediate Outcomes At Different Levels of Advertising Frequency." Journal of Advertising Research 59 (1): 27-39.

${ }^{103}$ Burton, Jennifer Lee, Jan Gollins, Linda E. McNeely, and Danielle M. Walls. 2019. "Revisiting the Relationship between Ad Frequency and Purchase Intentions: How Affect and Cognition Mediate Outcomes At Different Levels of Advertising Frequency." Journal of Advertising Research 59 (1): 27-39.

${ }^{104}$ Belch, George E. and Belch, Michael A. Advertising and Promotion: An Integrated Marketing Communications Perspective. New York: McGraw-Hill Education, 2015.
} 
Vol 1 Issue 2 (2019)

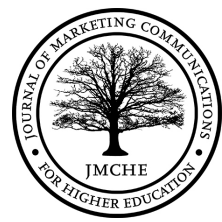

To review:

Phase One: Attention

- 1-2 Ad Exposures: Seek to gain attention through emotional drivers using category benefits.

Phase Two: Purchase Consideration and Evaluation

- 3-10 Ad Exposures: Focus messages on benefits of brand, position of brand or reasons to believe brand claims.

Phase Three: Action

- 10+ Ad Exposures: Use emotional benefits to reinforce consumers' belief about brand or help rationalize attitudes/behaviors toward brand.

\section{Implications}

- This work provides ample evidence to reconsider the practice of varying only the creative throughout the entirety of the campaign. Considering the evidence to support achieving higher frequency, campaigns that are planned in a more linear-having the message evolve - fashion, may result in stronger brand effects. Moreover, a detailed understanding of information seeking patterns will enable marketers to build familiarity first, and then use messaging to guide consumers through the evaluation stages of the decision-making process.

- Not only does this research provide a road map for message development, but could act as a way to build an integrated approach to communications planning over the course of college search. Marketers can match the communications tactic with the appropriate phase, and knowing the budget allocation for each, maximize the media spend and message throughout the customer journey.

\section{Conclusion}

There is still a need for higher ed marketers to do mass marketing. Digital advertising has not only given marketers new ways to evolve advertising but also new possibilities to integrate efforts across all channels. Given the many resource limitations those in this industry often experience, developing new ways in which each component of the marketing mix can be enhanced with digital advertising, or simply better ways to deploy digital advertising strategies, is critical. Institutions that are able to home in on a very specific market will still find the use of strategies above. 
Vol 1 Issue 2 (2019)

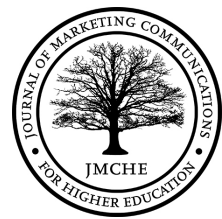

\section{References}

Advertising Research Foundation. 2018. Video impact: The value of mass marketing compared to targeting. WARC. https://www.warc.com/content/article/arf-

kif/video_impact_the_value_of_mass_marketing_compared_to_targeting/122944

Alhabash, Saleema, Anna R. McAlister, Wonkyung Kim, Chen Lou, Carie Cunningham, Elizabeth Taylor Quilliam \& Jef I. Richards. 2016. "Saw It on Facebook, Drank It at the Bar! Effects of Exposure to Facebook Alcohol Ads on Alcohol-Related Behaviors." Journal of Interactive Advertising. 16 (1): 44-58.

Ambler, Tim, and E. Ann Hollier. 2004. "The Waste in Advertising Is the Part That Works." Journal of Advertising Research 44 (4): 375-89.

Bakopoulos, Vassilis, John Baronello, and Rex Briggs. 2017. "How Brands Can Make Smarter Decisions in Mobile Marketing: Strategies for Improved Media-Mix Effectiveness And Questions for Future Research.” Journal of Advertising Research 57 (4): 447-61.

Bart, Yakov, Andrew T. Stephen, and Miklos Sarvary. 2014. "Which Products Are Best Suited to Mobile Advertising? A Field Study of Mobile Display Advertising Effects on Consumer Attitudes and Intentions." Journal of Marketing Research (JMR) 51 (3): 270-85.

Belch, George E. \& Belch, Michael A. Advertising and Promotion: An Integrated Marketing Communications Perspective. New York: McGraw-Hill Education, 2015.

Baron, Shawn D., Caryn Brouwer, and Amaya Garbayo. 2014. "A Model for Delivering Branding Value Through High-Impact Digital Advertising." Journal of Advertising Research 54 (3): 286-91

Benet, Les. \& Field, Peter. The Long and the Short of It: Balancing Short and Long-Term Marketing Strategies. London: IPA, 2013.

Benet, Les \& Field, Peter. Media in Focus: Marketing Effectiveness in the Digital Age. London: IPA, 2017. https://effworks.co.uk/wpcontent/uploads/2017/10/MEDIA_IN_FOCUS_FINAL_PDF_909.pdf

Bernard, M. 2001. Developing Schemas for the Location of Common Web Objects. Human Factors and Ergonomics Society Annual Meeting Proceedings. 45(15):1161-1165.

Bhardwaj, Bhanu and Chris Bacon. 2017. Cookies versus Context: How Contextually Relevant Advertising Drives Consumer Impact; May Improve ROI up to 30\%. https://www.iriworldwide.com/IRI/media/IRI_CookiesvsContext_TechPaper_SinglePage.pdf

(C) 2019 Christopher Huebner, MMC, M Ed.

This open access article is licensed under a Creative Commons Attribution: Non-Commercial license.

DOI: JMCHE/v1i201 
Biglione, Shann. To Target Or Not To Target, That Is Not The Question. In Snijders, W (Eds.), Eat Your Greens: Fact-based thinking to improve your brand's health. Leicester: Matador Publishing, 2018.

Blumenstein, Howard and Brianne Janacek Reeber. 2017. "5 charts that prove viewability and audibility together are key to video ad effectiveness." Think with Google.

https://www.thinkwithgoogle.com/advertising-channels/video/effective-video-ads-viewabilityaudibility/

Burton, Jennifer Lee, Jan Gollins, Linda E. McNeely, and Danielle M. Walls. 2019. "Revisiting the Relationship between Ad Frequency and Purchase Intentions: How Affect and Cognition Mediate Outcomes At Different Levels of Advertising Frequency." Journal of Advertising Research 59 (1): 27-39.

Cauberghe, Verolien, and Patrick De Pelsmacker. 2008. "The Advertising Impact of an Interactive TV Program on the Recall of an Embedded Commercial." Journal of Advertising Research 48 (3): 352-62.

Chang, Yuhmiin, and Esther Thorson. 2004. "Television and Web Advertising Synergies." Journal of Advertising 33 (2): 75-84.

Chappell, Matt. N.d. "Measuring the effectiveness of social media for FMCG." IPA Social Works.

https://www.marketingsociety.com/sites/default/files/LYSOLCASESTUDY_2\%281\%29.PDF

Chang, Yuhmiin and Thorson, Esther. 2004. "Television and Web Advertising Synergies." Journal of Advertising 33 (2): 75-84.

Cheong, Yunjae, Federico De Gregorio, and Kihan Kim. 2010. "The Power of Reach and Frequency In the Age of Digital Advertising." Journal of Advertising Research 50 (4): 403-15.

Shu-Chuan Chu, Sara Kamal \& Yoojung Kim. 2013. "Understanding consumers' responses toward social media advertising and purchase intention toward luxury products." Journal of Global Fashion Marketing. 4 (3), 158-174.

Shu-Chuan Chu, Sara Kamal \& Yoojung Kim. 2019. "Re-examining of consumers' responses toward social media advertising and purchase intention toward luxury products from 2013 to 2018: A retrospective commentary.“ Journal of Global Fashion Marketing. 10 (1), 81-92.

Cook, Karla. 2016. “A Brief History of Online Advertising. "Hubspot.com. https://blog.hubspot.com/marketing/history-of-online-advertising 
Dao, William Van-Tien, Angelina Nhat Hanh Le, Julian Ming-Sung Cheng and Der Chao Chen. 2014. "Social media advertising value." International Journal of Advertising, 33 (2), 271-294,

Daykin, Jerry. 2016. "The Wizarding World of Digital Marketing.” LinkedIn.

https://www.linkedin.com/pulse/wizarding-world-digital-marketing-digitalsense-jerrydaykin/?forceNoSplash=true

Donvito, Raffaele., \& Raithel, Sascha. 2014. "Marketing mix and customer equity of SPA brands: Cross-cultural perspectives." Journal of Business Research. 67 (10), 2155-2163.

Facebook IQ. 2016. "Reach Matters: Driving Business Results at Scale.” Facebook Business. https://scontent-iad3-1.xx.fbcdn.net/v/t39.23656/18159135_1778340622479708_1200639772381413376_n.pdf?_nc_cat $=104 \&$ _nc_ht $=$ scontent -iad3-1.xx\&oh=3c3f7a3de4e581 da5e2fb75e2ba461 cf\&oe $=5 \mathrm{CF} 148 \mathrm{~B} 1$

Fisher, Lauren. 2018. "eMarketer Releases Latest US Programmatic Ad Spending Forecast." eMarketer. https://www.emarketer.com/content/emarketer-releases-latest-us-programmatic-adspending-forecast

Flosi, Stephanie, Gian Fulgoni, and Andrea Vollman. 2013. "If an Advertisement Runs Online and No One Sees It, Is It Still an Ad? Empirical Generalizations in Digital Advertising." Journal of Advertising Research 53 (2): 192-99.

Frederick, Ben. 2016. “60\% Of All Mobile Banner Ad Clicks Are Accidents.” MoBlog. https:/www.mediapost.com/publications/article/268266/60-of-all-mobile-banner-ad-clicks-areaccidents.html

Fulgoni, Gian M., and Marie Pauline Mörn. 2009. "Whither the Click? How Online Advertising Works." Journal of Advertising Research 49 (2): 134-42.

Fulgoni, Gian M. 2013. "Big Data: Friend or Foe of Digital Advertising? Five Ways Marketers Should Use Digital Big Data to Their Advantage." Journal of Advertising Research 53 (4): 372 76.

Fulgoni, Gian M. 2015. "How Brands Using Social Media Ignite Marketing and Drive Growth." Journal of Advertising Research 55 (3): 232-36.

Fulgoni, Gian. M. 2016. "How to maximize the return on investment in digital marketing." WARC.

https://www.warc.com/content/paywall/article/bestprac/how_to_maximize_the_return_on_invest ment_from_digital_marketing/107001 
Vol 1 Issue 2 (2019)

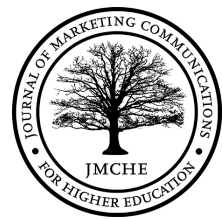

Fulgoni, Gian M. 2018. “Are You Targeting Too Much? Effective Marketing Strategies for Brands." Journal of Advertising Research 58 (1): 8-11.

Fulgoni, Gian M., and Andrew Lipsman. 2014. "Digital Game Changers: How Social Media Will Help Usher in The Era of Mobile and Multi-Platform Campaign-Effectiveness Measurement." Journal of Advertising Research 54 (1): 11-16.

Fulgoni, Gian M., and Andrew Lipsman. 2017. "Are You Using the Right Mobile Advertising Metrics? How Relevant Mobile Measures Change the Cross-Platform Advertising Equation." Journal of Advertising Research 57 (3): 245-49.

Ghose, Anindya, Avi Goldfarb, and Sang Pil Han. 2013. "How Is the Mobile Internet Different? Search Costs and Local Activities." Information Systems Research 24 (3): 613-31.

Google \& comScore. 2006. "comScore Press Release Study Confirms the Importance of Search in influencing Offline buying." comScore.

http://www.comscore.com/press/release.asp?press $=796$

Greenfield, Rebecca. 2014. "The Trailblazing, Candy-Colored History of the Online Banner Ad." Fast Company. https://www.fastcompany.com/3037484/the-trailblazing-candy-coloredhistory-of-the-online-banner-ad

Grewal, Dhruv, Yakov Bart, Martin Spann and Peter Pal Zubcsek. 2016. "Mobile Advertising: A Framework and Research Agenda." Journal of Interactive Marketing. 34: 3-14.

Ha, Louisa, and Kim McCann. 2008. "An Integrated Model of Advertising Clutter in Offline and Online Media." International Journal of Advertising 27 (4): 569-92.

Hervet, Guillaume, Katherine Guérard, Sébastien Tremblay, and Mohamed Saber Chtourou. 2011. "Is Banner Blindness Genuine? Eye Tracking Internet Text Advertising." Applied Cognitive Psychology 25 (5): 708-16.

Hoglund, G. \& Syvertsson, A. (2018). The causes and effects of native advertising clutter in social media. (Master's thesis, Stockholm School of Economics. Retrieved from http://arc.hhs.se/download.aspx?MediumId=4050

Hollis, Nigel. 2001. “Is Bigger Really Better?” ESOMAR Latin American Conference.

Hollis, Nigel. 2005. "Ten Years of Learning on How Online Advertising Builds Brands." Journal of Advertising Research 45 (2): 255-68. 


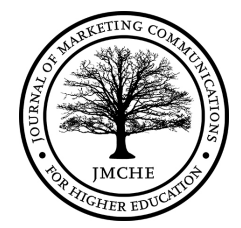

Hollis, Nigel. 2012. "Do not optimize on click-through if you want to build your brand online." Millward Brown.com. http://www.millwardbrown.com/global-navigation/blogs/post/mbblog/2012/07/30/Do-not-optimize-on-click-through-if-you-want-to-build-your-brand-online.aspx

Hwang, Tim and Adi Kamdar. 2013. "The Theory of Peak Advertising And the Future of the Web." Nesson Center for Internet Geophysics http://peakads.org/images/Peak_Ads.pdf Knoll, Johannes. 2016. "Advertising in Social Media: A Review of Empirical Evidence." International Journal of Advertising 35 (2): 266-300.

Koetsier, John. 2018. "Mobile Advertising Will Drive 75\% Of All Digital Ad Spend In 2018: Here's What's Changing” Forbes https://www.forbes.com/sites/johnkoetsier/2018/02/23/mobileadvertising-will-drive-75-of-all-digital-ad-spend-in-2018-heres-whats-changing/\#4b84b3d8758b

Kuisma, Jarmo. "Consumer Perception of Online Advertising: The Effects of Animation, Ad Characteristics, Repetition, Task Relevancy on Attention and Memory." (Unpublished doctoral dissertation, Aalto University, Helsinki, Finland, 2015).

Laroche, Michel, Isar Kiani, Nectarios Economakis, and Marie-Odile Richard. 2013. "Effects of Multi-Channel Marketing on Consumers' Online Search Behavior: The Power of Multiple Points of Connection." Journal of Advertising Research 53 (4): 431-43

Lewis, Randall A., and Justin M. Rao. 2015. "The Unfavorable Economics of Measuring the Returns to Advertising." Quarterly Journal of Economics 130 (4): 1941-73.

Lovelace Jr., Berkeley. 2017. "Half the number of online ad clicks are by mistake, says a Silicon Valley veteran. CNBC." https:/www.cnbc.com/2017/04/26/half-the-online-ad-clicks-are-bymistake-says-silicon-valley-veteran.html

Manchanda, Puneet, Jean-Pierre Dubé, Khim Yong Goh, and Pradeep K. Chintagunta. 2006. "The Effect of Banner Advertising on Internet Purchasing." Journal of Marketing Research (JMR) 43 (1): 98-108.

Millward Brown Interactive. “1997 IAB Online Advertising Effectiveness Study”. San Francisco, CA: Millward Brown Interactive, 1997.

Millward Brown. 2016. "Brand Lift Insights: Maximize advertising impact on brand perceptions." Millward Brown. http://www.millwardbrown.com/mb-global/what-we-do/mediadigital/media-effectiveness/brand-lift-insights

Millward Brown. 2017. “Getting Media Right 2017.” Millward Brown https:/www.millwardbrowndigital.com/research-insights/getting-media-right-2017/ 
Vol 1 Issue 2 (2019)

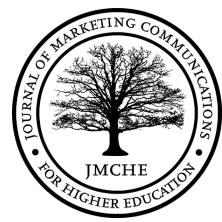

Millward Brown and Hotwired. 1996. The Hotwired Advertising Effectiveness Study. Hotwired.

Naik, Prasada A., and Kalyan Raman. 2003. "Understanding the Impact of Synergy in Multimedia Communications." Journal of Marketing Research (JMR) 40 (4): 375-88.

Navarro-Bailón, MaríaÁngeles. 2012. "Strategic Consistent Messages in Cross-Tool Campaigns: Effects on Brand Image and Brand Attitude." Journal of Marketing Communications 18 (3): 189-202.

Neff, Jeff. "The World According to Byron Sharp." Ad Age. https://adage.com/article/cmostrategy/the-world-according-to-byron-sharp-customer-loyalty-cheating/309532/

Neijens, Peter, and Hilde Voorveld. 2015. "Cross-Platform Advertising: Current Practices and Issues for the Future.” Journal of Advertising Research 55 (4): 362-67.

Nielsen. (2012). State of the Media: U.S. Digital Consumer Report. https://www.slideshare.net/blueeyepathrec/

Pappachen, George and Kara Manatt. 2008. "The Mobile Brand Experience: Measuring Advertising Effectiveness on the Mobile Web." ESOMAR.

www.esomar.org/web/research_papers/Advertising-Research_1828_The-Mobile-BrandExperience.php]

Powers, Todd, Dorothy Avdinccula, Manila S. Austin, Stacy Graiko, and Jasper Snyder. 2012. "Digital and Social Media In the Purchase Decision Process: A Special Report from the Advertising Research Foundation.” Journal of Advertising Research 52 (4): 479-89.

Raudeliuniene, Jurgita, Vida Davidaviciene, Manuela Tvaronaviciene and Laimonas Jonuska. 2018. "Evaluation of Advertising Campaigns on Social Media Networks." MDPI

Reuters 2016. "Social Media Ad Spending Is Expected to Pass Newspapers by 2020." Fortune. http://fortune.com/2016/12/05/social-media-ad-spending-newspapers-zenith-2020/

Romaniuk, Jenni and Byron Sharp. How Brands Grow: Part 2: Emerging Markets, Services, Durables, New and Luxury Brands. Oxford: Oxford University Press, 2015.

Shankar, Venkatesh and Balasubramanian, Sridhar. 2009. "Mobile Marketing: A Synthesis and Prognosis." Journal of Interactive Marketing. 23(2). 118-129.

Sharp, Byron. How Brands Grow: What Marketers Don't Know. Oxford: Oxford University Press, 2010. 
Shebbeare, Andrew. 2014. "Everything You Know About Frequency is Wrong." AdExchanger. http://adexchanger.com/data-driven-thinking/everything-know-frequency-wrong/

Shields, Ronan. 2016. "“Fat thumbs' generate up to $60 \%$ of mobile ad clicks." The Drum. https://www.thedrum.com/news/2016/02/03/fat-thumbs-generate-60-mobile-ad-clicks

Simler, Kevin. 2014. “Ads Don’t Work That Way.” Melting Asphalt.

https://meltingasphalt.com/ads-dont-work-that-way/

Smallwood, Brad. 2016. "Resisting the Siren Call Of Popular Digital Media Measures." Journal of Advertising Research 56 (2): 126-31

Snyder, Jasper, and Manuel Garcia-Garcia. 2016. "Advertising across Platforms: Conditions for Multimedia Campaigns." Journal of Advertising Research 56 (4): 352-67.

Sterling, Greg. 2018. "Forecast downgrades 2018 Snap ad-revenue outlook by 36 percent." Marketing Land https://marketingland.com/forecast-downgrades-2018-snap-ad-revenue-outlookby-36-percent-249332

Stipp, Horst. 2018. "How Context Can Make Advertising More Effective.” Journal of Advertising Research 58 (2): 138-45.

Stuart, Greg, Vassilis Bakopoulos and Rex Briggs. 2016. "Why mobile marketing is a missed opportunity- And how you can optimize it on behalf of your brand." Journal of Brand Strategy. 5(2). 1-10.

Tan, Wei Son, Choon Ling Kwek and Zhongwei Li. 2013. "The Antecedents of Effectiveness Interactive Advertising in the Social Media.” International Business Research. 6(3). 88-89.

Taylor, Jennifer, Rachel Kennedy, Colin McDonald, Laurent Larguinat, Yassinne El Ouarzazi, and Nassim Haddad. 2013. "Is the Multi-Platform Whole More Powerful Than Its Separate Parts? Measuring the Sales Effects of Cross-Media Advertising." Journal of Advertising Research 53 (2): 200-211.

The Interactive Advertising Bureau. 2018. "IAB internet advertising revenue report" https://www.iab.com/wp-content/uploads/2018/11/REPORT-IAB-Internet-Advertising-RevenueReport-HY-2018.pdf

The Nielsen Company. 2012. "Click-Thru Rates Mislead Brand Marketers On Online Campaign. " The Nielsen Company https://www.nielsen.com/us/en/insights/news/2012/clickthru-rates-mislead-brand-marketers-on-online-campaign-performance.html 
The Nielsen Company. 2016. "Beyond Clicks and Impressions: Examining the Relationship Between Online Advertising and Brand Building." The Nielsen Company

https:/www.nielsen.com/content/dam/corporate/us/en/reports-downloads/2011-Reports/NielsenBeyond-Clicks-and-Impressions.pdf

Voorveld, Hilde A.M., Peter C. Neijens, and Edith G. Smit. 2011. "Opening the Black Box: Understanding Cross-Media Effects.” Journal of Marketing Communications 17 (2): 69-85. Wind, Yoram, Byron Sharp and Karen Nelson-Field. 2013. "Empirical Generalizations: New Laws for Digital Marketing: How Advertising Research Must Change." Journal of Advertising Research 53 (2): 175-80.

Zuckerman, Ethan. 2014. "The Internet's Original Sin: It's not too late to ditch the ad-based business model and build a better web." The Atlantic.

https://www.theatlantic.com/technology/archive/2014/08/advertising-is-the-internets-original$\sin / 376041 /$ 